Rapp. Grønlands geol. Unders. 99, 111-118 (1980)

\title{
Sr-ISOTOPIC STUDIES AND MINERAL COMPOSITION OF THE HAGEN BRÆ MEMBER IN THE PROTEROZOIC CLASTIC SEDIMENTS AT HAGEN BRÆ, EASTERN NORTH GREENLAND
}

\author{
Ole Larsen and Poul Graff-Petersen
}

During the field season of 1978, siltstones from the Hagen Bræ Member of the Proterozoic Independence Fjord Group were sampled for isotopic dating by John Collinson (Collinson, this report). The samples were collected from the north side of Hagen Bræ along two profiles separated by approximately $800 \mathrm{~m}$ (Collinson, 1979 and this report, fig. 8, locality B). The total thickness of the siltstones from the unconformity below the siltstone beds to the feldspathic sandstone above is approximately $40 \mathrm{~m}$. The samples appear to represent the lower third of the member.

The siltstones are brightly red. Many samples display bleached spots with black centres around which iron, apparently, has been reduced and leached. In thin section layers of angular silt-size grains of quartz and $\mathrm{K}$-feldspar and sparse flakes of mica alternate with layers rich in clay minerals. The clastic mineral grains are cemented together by fine-grained carbonate. The relative amounts of silt-size material, clay, and carbonate vary considerably, and some of the samples rich in clay may by termed claystones rather than siltstones.

\section{Experimental}

The samples were crushed carefully in order to prevent further reduction in size of the detrital grains. The carbonates were extracted by treatment with $2 \mathrm{~N}$ acetic acid at room temperature for 18 hours. The clay fraction (less than $2 \mu \mathrm{m}$ ) was separated from silt-size grains in a centrifuge and flocculated with $\mathrm{NH}_{4} \mathrm{Cl}$. A minor fraction of the clay was stored as wet paste for oriented X-ray diffraction studies, while the major part of the sample was dried and crushed to fine powder for X-ray fluorescence analysis (XRF) and for isotopic analysis of strontium.

The solution containing cations from the dissolved carbonates was evaporated to dryness on a hot plate, and the mixture of acetates was analysed by XRF, atomic absorption spectrometry (AAS) and mass spectrometry. The magnesium content was determined by AAS. Ca was not determined separately, but was calculated by difference. Fe could not be detected in the acetate.

\section{Geochemical studies}

As may be seen from Table 4, the geochemical parameters vary in a regular manner along the two vertical profiles sampled. The content of carbonate appears to decrease upwards. In the lower parts of the profiles more than 10 per cent of the siltstone is carbonate, whereas the three samples collected higher in the sections contain only a few percent carbonate.

The $\mathrm{Mg}$ content of the carbonate, calculated as the $\mathrm{Mg} / \mathrm{Ca}$ ratio (Table 4), varies by a factor of 10 . The $\mathrm{Mg} / \mathrm{Ca}$ ratios display a bimodal distribution with a low ratio group between 
Table 4. Tentative stratigraphic correlation and comparative data of the siltstone samples from Hagen Brae

\begin{tabular}{|c|c|c|c|c|c|c|c|c|c|c|c|}
\hline \multicolumn{6}{|c|}{ Profile A } & \multicolumn{6}{|c|}{ Profile B } \\
\hline Sample & $\begin{array}{l}\text { Carbonate } \\
\% \text { of rock }\end{array}$ & $\begin{array}{c}\mathrm{Mg} / \mathrm{Ca} \\
\mathrm{mol} / \mathrm{mol}\end{array}$ & $\begin{array}{c}\mathrm{Sr} / \mathrm{Ca} \times 10^{3} \\
\mathrm{~mol} / \mathrm{mol}\end{array}$ & $\begin{array}{c}S r \\
\text { ppm }\end{array}$ & $\begin{array}{c}\text { Illite } \\
\% \text { of clay }\end{array}$ & Sample & $\begin{array}{l}\text { Carbonate } \\
\% \text { of rock }\end{array}$ & $\begin{array}{c}\mathrm{Mg} / \mathrm{Ca} \\
\mathrm{mol} / \mathrm{mol}\end{array}$ & $\begin{array}{c}\mathrm{Sr} / \mathrm{Ca} \times 10^{3} \\
\mathrm{~mol} / \mathrm{mol}\end{array}$ & $\begin{array}{c}\mathrm{Sr} \\
\mathrm{ppm}\end{array}$ & $\begin{array}{c}\text { Illite } \\
\% \text { of clay }\end{array}$ \\
\hline 273112 & 5 & 1.1 & 40 & 940 & 17 & $\begin{array}{l}273119 \\
273118\end{array}$ & $\begin{array}{l}3 \\
8\end{array}$ & $\begin{array}{l}1.3 \\
1.0\end{array}$ & $\begin{array}{l}63 \\
26\end{array}$ & $\begin{array}{l}830 \\
980\end{array}$ & $\begin{array}{r}11 \\
6\end{array}$ \\
\hline 273111 & 7 & 0.20 & 17 & 960 & 7 & & & & & & \\
\hline 273110 & 9 & 0.14 & 12 & 850 & 3 & 273117 & 11 & 0.19 & 13 & 1030 & 8 \\
\hline 273109 & 20 & 0.09 & 4 & 650 & 1 & 273116 & 13 & 0.10 & 8 & 860 & 2 \\
\hline 273108 & 19 & 0.09 & 4 & 640 & 1 & $\begin{array}{l}273115 \\
273114 \\
273113\end{array}$ & $\begin{array}{l}15 \\
19 \\
20\end{array}$ & $\begin{array}{l}0.12 \\
0.13 \\
1.2\end{array}$ & $\begin{array}{l}7 \\
4 \\
6\end{array}$ & $\begin{array}{l}850 \\
600 \\
470\end{array}$ & $\begin{array}{l}4 \\
6 \\
1\end{array}$ \\
\hline
\end{tabular}

0.1 and 0.2 and a high ratio group near 1.0. The latter ratio corresponds to that of pure dolomite. The sediments from the top and bottom of the sampled sequence are apparently dolomitic, whereas samples from the middle part of the profiles are mainly calcitic (Table 4).

$\mathrm{The} \mathrm{Sr} / \mathrm{Ca}$ ratio for the carbonate is very high for a Precambrian sediment (Veizer, 1977). $\mathrm{Sr} / \mathrm{Ca} \times 10^{3}$ ratios are commonly less than one in older Phanerozoic and Proterozoic rocks. Ratios above one are taken to indicate penecontemporaneous to early-diagenetic formation of dolomite in a hypersaline depositional environment (Veizer et al, 1978). Collinson (1979) reports the occurrence of salt pseudomorphs in the siltstones, and he envisages the depositional environment as that of a shallow, intracratonic lake subjected to periodic marine incursions.

Table 5 shows the major element composition of a siltstone sample containing only 5 per cent of dolomitic carbonate (273112). The iron is highly oxidised, as may be expected from the intense red coloration of the siltstones. The $\mathrm{Mg}$ content is high. The dolomite will account for some magnesium, but the bulk of the recorded $\mathrm{MgO}$ must be attributed to the clay minerals. $\mathrm{Na}_{2} \mathrm{O}$ is very low, while $\mathrm{K}_{2} \mathrm{O}$ is high. Some potassium is, no doubt, due to

Table 5. Whole rock analysis of a siltstone from Hagen Bra.

\begin{tabular}{lr}
\hline Sample & 273112 \\
\hline $\mathrm{SiO}_{2}$ & 55.84 \\
$\mathrm{TiO}_{2}$ & 0.58 \\
$\mathrm{Al}_{2} \mathrm{O}_{3}$ & 15.40 \\
$\mathrm{Fe}_{2} \mathrm{O}_{3}$ & 5.56 \\
$\mathrm{FeO}_{\mathrm{MnO}}$ & 0.31 \\
$\mathrm{MgO}$ & 0.10 \\
$\mathrm{CaO}$ & 6.06 \\
$\mathrm{Na}_{2} \mathrm{O}$ & 1.69 \\
$\mathrm{~K}_{2} \mathrm{O}$ & 0.09 \\
$\mathrm{P}_{2} \mathrm{O}_{5}$ & 8.95 \\
$\mathrm{H}_{2} \mathrm{O}^{+}$ & 0.15 \\
& 5.17 \\
\hline
\end{tabular}

GGU chemical laboratory.

Sample from top of profile B (see fig. 8). 


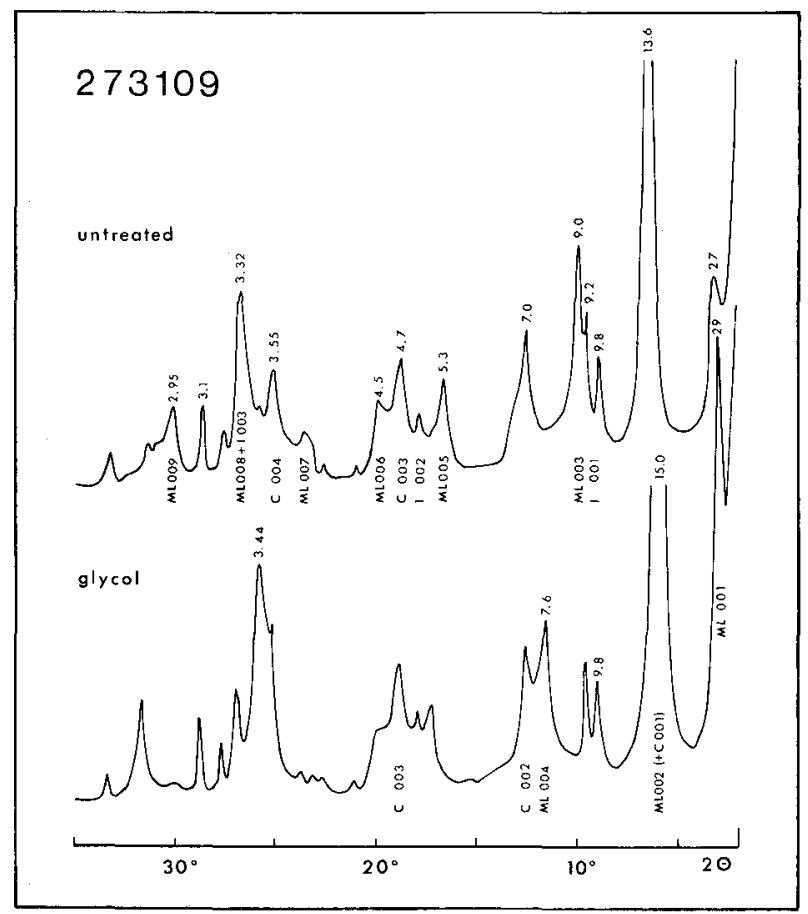

Fig. 49. X-ray diffraction curves obtained on oriented sample (natural and glycolated) of the clay fraction of siltstone sample 273109.

$\mathrm{K}$-feldspar present in the fraction above $2 \mu \mathrm{m}$. In order to check this the potassium content of the clay fraction was determined as well. $\mathrm{A} \mathrm{K}_{2} \mathrm{O}$ content of 7.5 per cent suggests that potassic clay minerals may be present in considerable amounts in this sample.

\section{X-ray diffraction studies}

The X-ray diffraction spectra of the samples 273109 and 273114, shown in figs. 49 and 50 , illustrate important characteristics of all the samples investigated. The strongest reflection peak is located at $13.6 \AA$. At twice this basal spacing, $27 \AA$, a peak of weak to moderate intensity may be seen. Taking the $27 \AA$ reflection as (001) and the $13.6 \AA$ peak as $(002)$, all the integral basal reflections up to $(009)$ may be identified. The prominence of the uneven reflections in this series suggests that a chloritic mixed-layer clay mineral, with a considerable degree of ordering, is present in the clay. When the clay was exposed to ethylene glycol vapours overnight, no expansion could be detected, but after several days of treatment the mixed-layer clay mineral expanded from $13.6 \AA$ to $15 \AA$. Heating to $550^{\circ} \mathrm{C}$ diminished the (002) basal spacing to $11.5 \AA$, fig. 50. These observations indicate a three-component, mixed-layer, clay mineral with a regular interlayering of chlorite, montmorillonite and illite. The relative amounts of the components mentioned have not yet been determined.

The prominent mixed-layer clay mineral includes illite interlayering. In sample 273109 , which contains very little $10 \AA$ illite, a $\mathrm{K}_{2} \mathrm{O}$ content of 2.7 per cent was recorded in the clay 


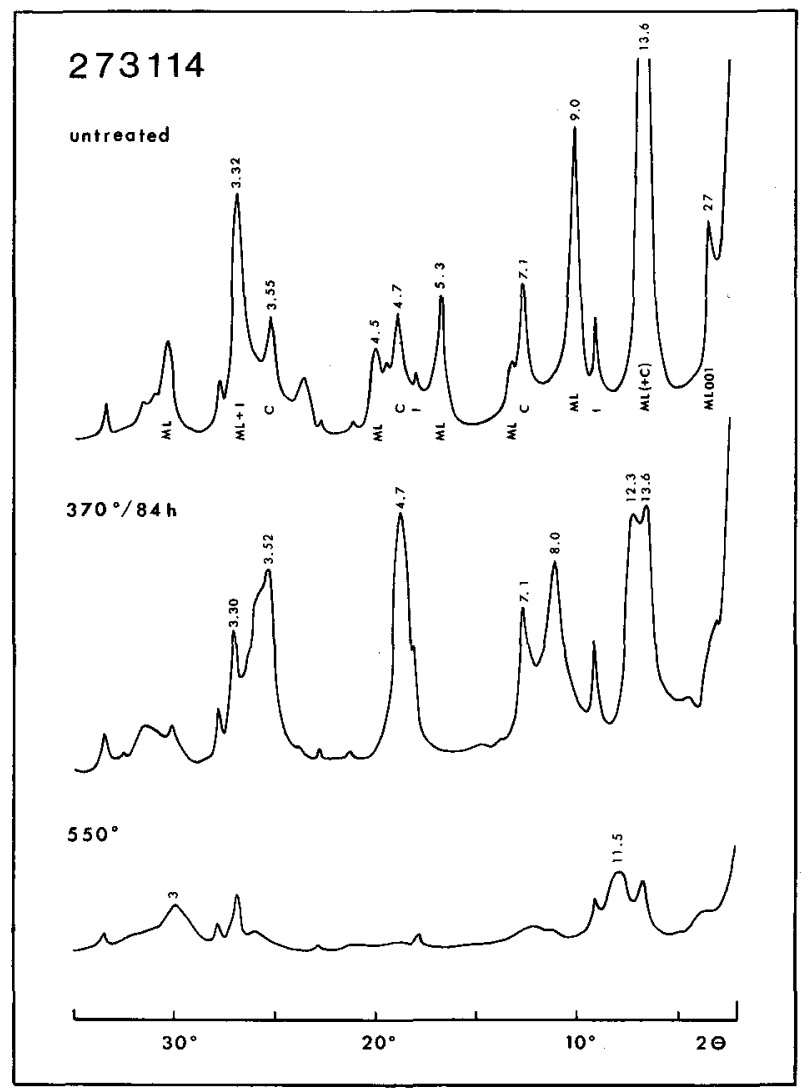

Fig. 50. X-ray diffraction curves obtained on oriented sample (natural and heated) of the clay fraction of siltstone sample 273114 .

fraction. This potassium is believed to reflect the illitic component in the mixed-layer clay mineral, which seems to dominate the clay fraction.

Diffraction curves, of treated and untreated samples, all show narrow peaks at $9.8 \AA, 4.9$ $\AA$ and $3.3 \AA$ ( $I$ on figs 49 and 50), which establishes the presence of a non-expandable, 10 $\AA$, micaceous illite. By adding known quantities of a standard illite (Marblehead, Wisconsin) to the clay samples, and comparing intensities of the $10 \AA$ and the $14 \AA$ diffraction peaks, estimates of the content of illite were obtained (Table 4). Sample 273112, of which the major element composition is given in Table 5, proved to be exceptionally rich in the illitic mineral component. Sample 273119, collected high up in profile B (Table 4), is also rich in illite.

Chlorite is present as a separate mineral as well as being a constituent of the mixed-layer clay mineral. Its presence is demonstrated by sharp peaks, marked $C$, at $7.1 \AA, 4.7 \AA$ and $3.55 \AA$, on figs 49 and 50 . The chlorite $3.55 \AA$ (004) reflection moved to $3.52 \AA$ upon heating to $370^{\circ} \mathrm{C}$ for 84 hours; a (002) peak for kaolinite would not move (Bradley, 1955).

Diffraction spectra of the fraction above $2 \mu \mathrm{m}$ are dominated by peaks of quartz and 
Fig. 51. Sr-isotopic compositions of whole rock samples of siltstones at Hagen Bræ.

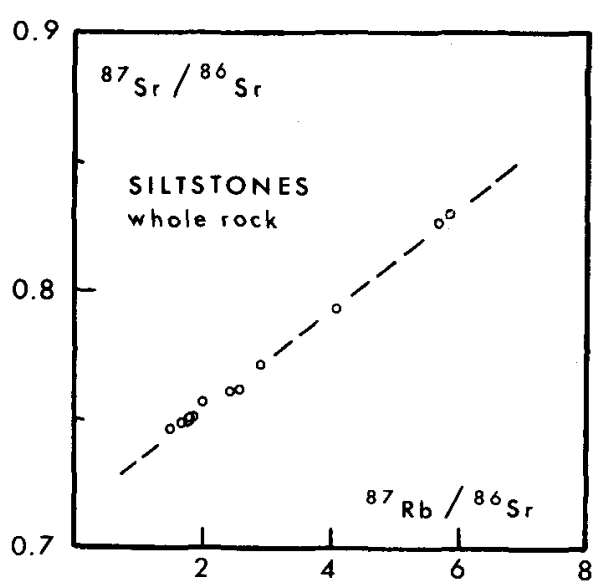

feldspar. In the diffraction spectra on oriented samples of the fraction less than $2 \mu \mathrm{m}$, only minor peaks indicate the presence of these detrital minerals. We believe that detrital minerals comprise only a minor part of the clay fraction.

\section{Isotopic studies}

$\mathrm{Rb} / \mathrm{Sr}$ ratios and isotopic compositions of strontium were measured on untreated, whole-rock samples as well as on carbonate-free, clay fractions. The whole-rock samples (WR) plotted in fig. 51 display a good linear relationship. However, a regression line through these data points should not be interpreted as an isochron.Each whole-rock sample is a mixture of three components which probably have not been in isotopic equilibrium at any time during the past: (1) the clay fraction, (2) the fraction above $2 \mu \mathrm{m}$ and (3) the carbonates. The clay fractions have high $\mathrm{Rb} / \mathrm{Sr}$ ratios (fig. 52). The carbonates have low $\mathrm{Rb} / \mathrm{Sr}$ ratios, and $\mathrm{Sr}$-isotopic ratios around 0.71 (fig. 53a).

The isotopic data on clay fractions, carbonates and whole-rock samples may be used to estimate the isotopic composition of the fraction above $2 \mu \mathrm{m}$, using mass balance calculations. These calculations are subject to considerable error, but the general positions of the points representing this fraction (fig. 53b) are believed to be correct. The points are seen to plot above the best fit line through the whole-rock data, and they appear to be distributed along a line slightly steeper than that for the whole-rock samples. The identification of quartz and feldspar as detrital components suggests that the points plotted in fig. 53b represent detrital K-feldspars which are isotopically characteristic of the source area.

Kalsbeek (personal communication) reports isotopic data for arkosic sandstones which are similar to the sandstones surrounding, and intercalating, the investigated siltstones. His samples display higher $\mathrm{Rb} / \mathrm{Sr}$ ratios than our computed data for the fraction above $2 \mu \mathrm{m}$, but it is interesting to note that the sandstones plot near the line along which the computed points are distributed. The pooled data suggest a minimum age of $1670 \mathrm{~m} . \mathrm{y}$. for the proposed common source region.

The clay fractions are not distributed along a single line (fig. 52). The samples have been 


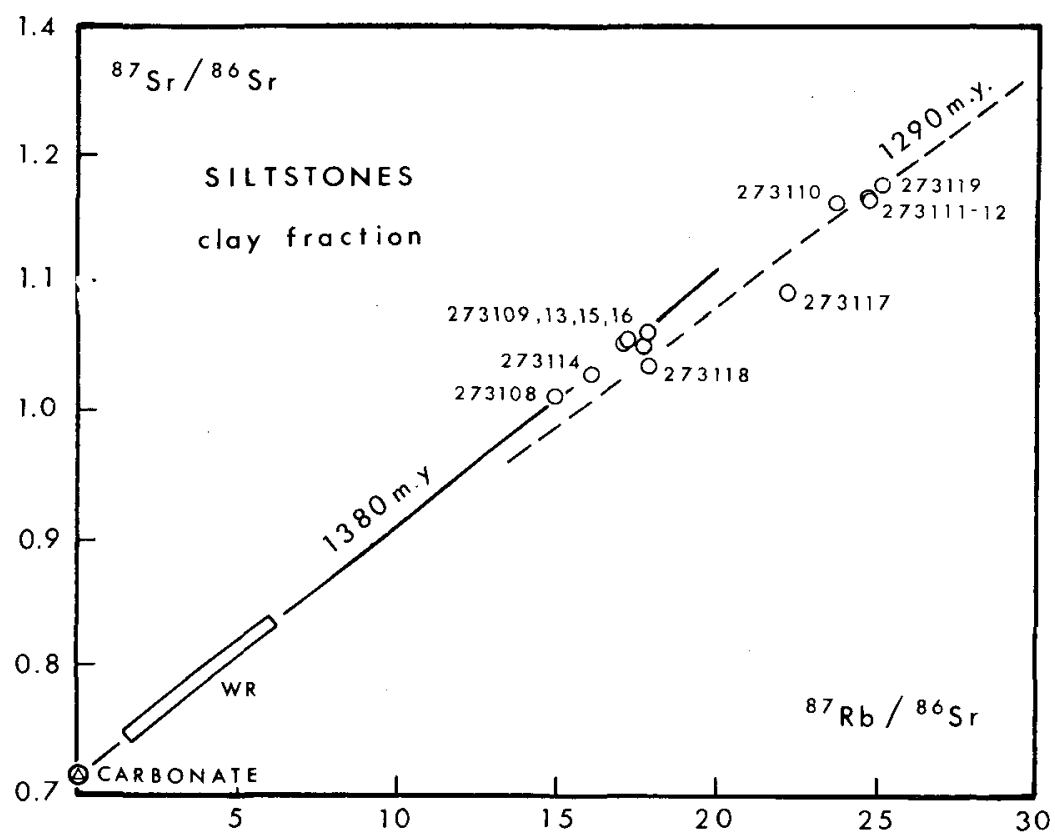

Fig. 52. Sr-isotopic compositions of clay fractions seperated from the siltstones at Hagen Bræ. The position of the whole rock samples and the carbonate fractions are shown for comparison. Decay constant $1.42 \times 10^{-11}$.

analysed twice with only minor variations in the analytical results. The samples 273110 , 273111, 273112 and 273119 display high, and quite similar, $\mathrm{Rb} / \mathrm{Sr}$ and $\mathrm{Sr}$-isotopic ratios. The same 4 samples have higher ${ }^{87} \mathrm{Sr} /{ }^{86} \mathrm{Sr}$ ratios, and higher $\mathrm{Rb} / \mathrm{Sr}$ ratios, in the carbonates than the rest of the samples (fig. 53a). The steep linear trend observed in fig. 53a, suggests that radiogenic $\mathrm{Sr}$ was extracted from the clay fraction in preference to normal $\mathrm{Sr}$ (and $\mathrm{Rb}$ ). This is in agreement with the results of other authors and can be explained. The problem remains: when did this extraction take place? The extraction of radiogenic strontium may have been caused by the treatment of the sample with acetic acid. If this is the case, a weaker acid or a buffered solution should be used for future work. This interpretation may be supported, in particular, by the increased $\mathrm{Rb}$ content recorded in the acetate of the four samples mentioned above.

However, we cannot exclude the possibility that these samples lost radiogenic strontium to the carbonate phase some time in the past. Evidence for this interpretation may be found in the fact that three of the four critical samples plot very close to each other, as may be seen on the plot of fig. 52. If the acid treatment has leached Sr from the clays, a wider spread of data points would be expected. Sample 273117 differs in $\mathrm{Sr}$-isotopic and $\mathrm{Rb} / \mathrm{Sr}$ ratios from the four leached samples, and also from the other samples of the clay fractions (fig. 52). If we use clay + carbonate to calculate an apparent age of isotopic equilibrium between these two components in samples $273111,273112,273118$ and 273119 , an age of $1290 \mathrm{~m} . \mathrm{y}$. is obtained. Sample 273110 does not quite follow the other three samples with high $\mathrm{Rb} / \mathrm{Sr}$ 

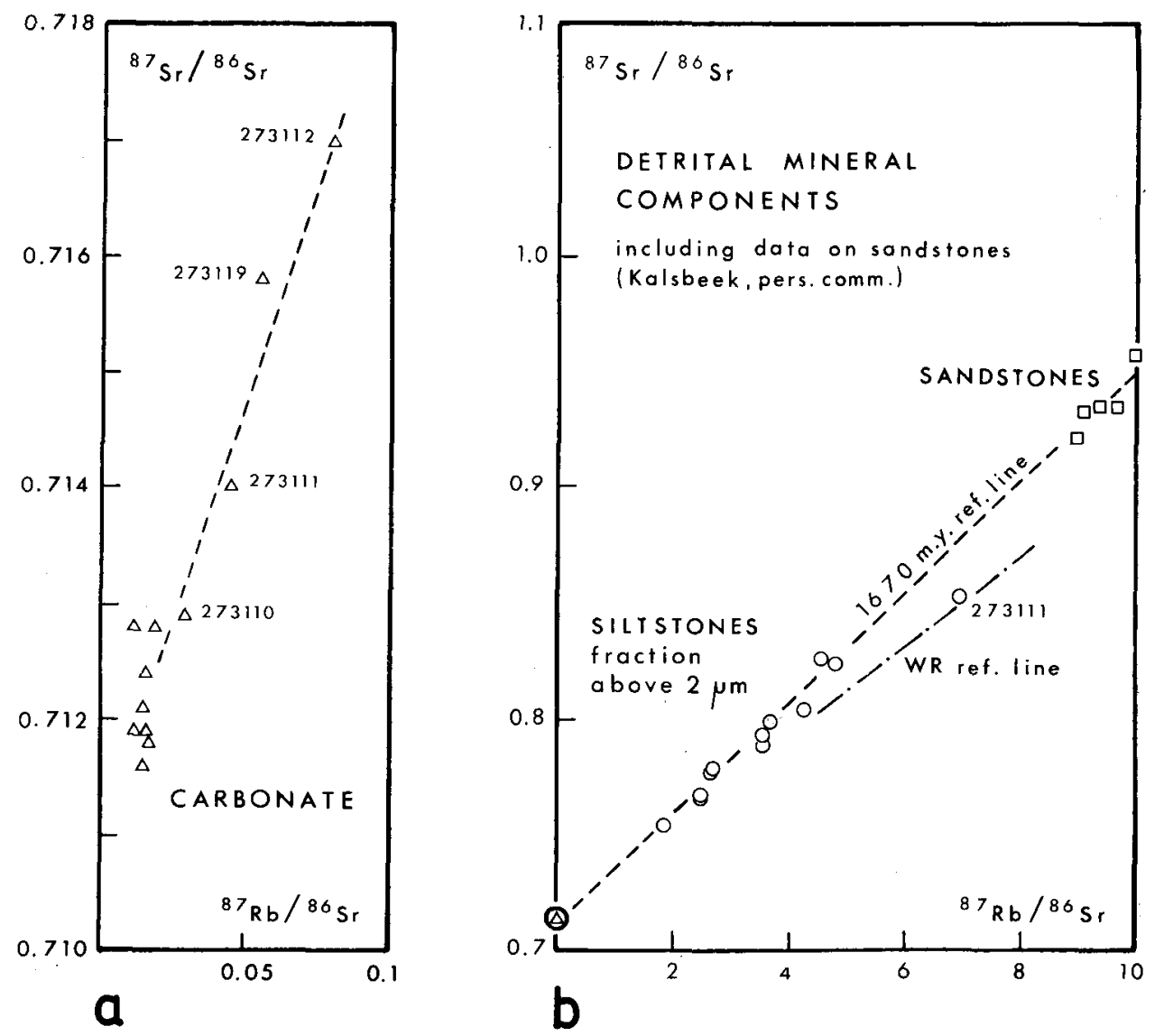

Fig. 53a. Sr-isotopic compositions of carbonates extracted with $2 \mathrm{~N}$ acetic acid from siltstones at Hagen Bræ. b. Sr-isotopic compositions of the carbonate-free fractions above $2 \mu \mathrm{m}$ obtained by mass balance calculations. The isotopic composition of carbonates and of five sandstone samples studied by Kalsbeek (this report) are shown for comparison.

ratios. We know that the Proterozoic clastic sediments of J. C. Christensen Land are intruded by a multitude of major dykes and sills. We know, from recent investigations (Jepsen \& Kalsbeek, 1979), that this intrusive activity took place shortly after $1300 \mathrm{~m}$. y. An age of $1290 \pm 70$ m.y. was obtained on a granophyre, exposed at Kap Einer Mikkelsen on the north side of Independence Fjord, while a granophyre dyke from Vildtland yielded 1230 25 m.y. Both of these ages are based on very good isochrons (MSWD 0.38 and 0.81 respectively). The error limits are reported at the 2 sigma confidence level, so it is possible that the results reported by Jepsen and Kalsbeek reflect different phases of intrusive activity. If the sediments were intruded by major dykes, it is not unlikely that this magmatic activity set up a circulation of hot water through the permeable parts of the sedimentary sequence, causing extraction of radiogenic $\mathrm{Sr}$ from the clay minerals, and probably also promoting diagenetic processes in the affected sediments. 
Whatever conclusion further investigations, now in progress, might lead to concerning the cause of the disturbances in the isotopic systems of the clay minerals, we must conclude that samples 273108-273109 and 273113-273116, all from the lower beds of the Hagen Bra Member, appear to be the ones least affected by leaching. We believe, that the mixed-layer clay mineral, which seems to dominate the clay fraction of all the samples, is the result of diagenesis. This mineral is believed to have formed in isotopic equilibrium with the surrounding carbonates. The $10 \AA$ non-expanding illite and the non-expanding chlorite could have retained isotopic characteristics of a source region, if they were of detrital origin. However, these mineral components do not appear to influence the $\mathrm{Sr}$-isotopic composition of the clay fraction.

It is suggested, that the clay fractions of the six samples listed above may be used to estimate the time of clay mineral diagenesis, in particular of the ordered mixed-layer clay mineral. An age of approximately $1380 \mathrm{~m} . \mathrm{y}$. was obtained.

\section{Conclusion}

Considering the hypersaline depositional environment, it is likely that the clay mineral diagenesis took place shortly after the time of deposition, as suggested by Peterson (1962). If this is true, we must conclude that the Hagen Bræ Member was deposited at approximately $1380 \mathrm{~m}$.y. However, intrusive activity could also have promoted diagenetic processes in the sediment and thus helped to reset the isotopic clocks. The reported age may, therefore, be taken only as a safe minimum age for this stratigraphic unit.

Acknowledgement. This study was supported by the Danish Natural Science Research Council.

\section{References}

Bradley, W. F. 1955: X-ray diffraction criteria for the characterization of chloritic material in sediments. Clays and Clay Minerals. Proc. third nat. Clay Conf. 324-334.

Collinson, J. D. 1979: The Proterozoic sandstones between Heilprin Land and Mylius-Erichsen Land, eastern North Greenland. Rapp. Grønlands geol. Unders. 88, 5-10.

Jepsen, H. F. \& Kalsbeek, F. 1979: Igneous rocks in the Proterozoic platform of eastern North Greenland. Rapp. Grønlands geol. Unders. 88, 11-14.

Peterson, M. N. A. 1962: The mineralogy and petrology of Upper Mississipian carbonate rocks of the Cumberland Plateau in Tennessee. J. Geol. 70, 1-31.

Veizer, J. 1977: Diagenesis of pre-Quaternary carbonates as indicated by tracer studies. J. Sedim. Petrol. 47, 565-579.

Veizer, J., Lemieux, J., Jones, B., Gibling, M. R. and Savelle, J. 1978: Paleosalinity and dolomitization of a Lower Paleozoic carbonate sequence, Somerset and Prince of Wales Islands, Arctic Canada. Can. J. Earth Sci. 15, 1448-1461. 